\title{
AROMATIC PLANT TRADE AND \\ LIVELIHOOD STRATEGIES IN RURAL NEPAL: A CASE OF WINTERGREEN IN DOLAKHA DISTRICT
}

Madhusudan Subedi *

\section{Introduction}

Collection and trading of non-timber forest products (NTFPs) is a traditional economic activity in $\mathrm{N}$ epal. For decades, the rural poor in the mid-hills and mountains have been involved in the collection and sale of NTFPs for their medicinal and aromatic value. Utilization of plant resources is expanding as more people recognize their value for health, environment and social justice (Rawal, A charya and Subedi 2001). These products constitute a significant portion of the rural economy and are locally consumed by communities living adjacent to the forest. Growing market opportunities for NTFPs provide real potential to raise local people's income, contribute to the national economy, and provide conservation incentives. However, the current NTFP sub-sector in Nepal is characterized by low level of knowledge among the collectors/ producers, low domestic -value addition, and poor integration across the value chain. A number of stakeholder groups, ranging from collectors, local middlemen, urban traders, manufacturers, exporters, and government agencies have been involved in the chain with their own varied interests (0jha, 2000).

In the rural areas of $\mathrm{N}$ epal where resources are relatively abundant and other income generating opportunities are limited, essential oil plants offer a good prospect for enhancing the livelihood and incomes of local

\footnotetext{
* Madhusudan Subedi holds M. A. in Sociology from Tribhuvan U niversity and M. Phil from the U niversity of Bergen, N orway. Currently, he teaches Sociology at the Central Department of Sociology/Anthropology.
} 
communities. $Y$ et, these opportunities are tapped only on a limited scale owing to lack of knowledge on marketing, entrepreneurial capability and financial resources. For the past several years, development workers and policy makers have discussed the possibility of promoting non-timber forest products to reduce poverty. However, it has been difficult to find economically attractive essential oil products. To be successful, an essential oil product must have lasting market appeal and not merely be a 'novelty item', collectors must receive a good income from the product, and distributors must be guaranteed a consistent supply of the product. Case studies, publications and field visits on different enterprises undertaken in the past have demonstrated that investments addressing the above success factors have improved the economic situation of the rural poor as well as strengthened local governance (IIED 1998; Kaplinksy and Morris 2001; Ribot 1997; Shillington 2002).

A gainst the above backdrop, the objective of this paper is to assess opportunities for W intergreen, a natural product's intervention on poverty reduction, strengthening local governance, and improving resource management.

\section{Framework of the Study}

Wintergreen is available in sufficient quantity to allow for sustainable commercial harvesting and has the potential to be brought under locally managed regeneration systems. Wintergreen oil has demonstrated commercial value at the national or international level in order to attract local participation which offers opportunities for value-addition and increased productivity at the local level, thereby leading to poverty alleviation.

This paper is based on the nature, wealth and power framework and the analysis utilizes the concept of value chain. A value chain is defined as "a series of interlinked exchanges through which a commodity and its constituents pass from extraction through production to end use (M endelson, Cowlishaw and Rowcliffe 2003:73)". As such, this approach directly addresses issues of production, transport and sale of the products to the final destination. One strength of the commodity chain approach is that it emphasizes on the fundamental importance not only of identifying 
86 Occasional Papers, Vol 11

the actors involved in the trade, but also of elucidating the structure of market and tracing the dispersion of the benefit and power along the chain as determined by various interests and power relations. It is an explanatory tool that has its origins in the study of global trade relations and impacts of globalization, and has been extensively used to analyze agricultural and natural resource commodity markets. Thus, this is the series of relations through which an item passes, from extraction through conversion, exchange, transport, distribution and final use. Access mapping involves evaluating the distribution of profits among and within the groups along the chain; and tracing out, or mapping, from that distribution the mechanisms by which access to benefit is maintained and controlled. It also illuminates the practical issues surrounding establishment of community participation in benefits from and control over natural resources.

This approach is based on the premise that a better understanding of natural, economic and governance dimensions of a natural product chain will aid in expanding options for value addition, improve distributional outcomes, and encourage sustainable resource management. One powerful tool for understanding a value chain is access mapping. This involves identifying the actors who extract, produce, process, exchange, transport, distribute and consume the commodity; evaluating income and profit at each level; evaluating the distribution of income and profit within each group; and tracing the mechanism by which access to benefits is maintained and controlled within each group (Ribot, 1998).

\section{Research M ethods Used:}

The study is based on the primary data collected using key informant interviews, focus group discussions, key informant interviews, and group interviews with a range of stakeholders from grassroots to national level stakeholders representing government and non-government institutions. To supplement the primary data, documentations were reviewed for using the relevenat data. Dolakha district was selected for the study where a large volume of Wintergreen is currently harvested from this district, and potential exists for its expanded commercial activities. The unit of analysis is Wintergreen, a specific natural product. 


\section{Nature, Habitat and E cology of W intergreen:}

Wintergreen, locally known as Dhasingre/Dhasingare/Machino, is one of the widely available natural products in D olakha district. Wintergreen is found between 1500-2700 meter feet in central Nepal and grows wild. It is a robust shrub with ovate to lanceolate evergreen leaves, and with numerous, axillary, spike-like clusters of small fragrant white or pink globular flowers. Flower clusters are $2.5-8.0 \mathrm{~cm}$ long, shorter than leaves; flowers are short-stalked; and corolla are $4 \mathrm{~mm}$ by $3 \mathrm{~mm}$ broad. Leaves are acute, 5-10 cm long, smooth above, dotted with the bases of bristles beneath, margins bristly-toothed; a branched shrub to 1-1.75 $\mathrm{m}$. fruit $0.6 \mathrm{~mm}$, with dark violet-blue fleshy pointed calyx-lobes.

This plant is native of North A merica and is found in woodland and exposed mountainous areas (Acharya, 2003). It is commonly found in $\mathrm{N}$ epal as wild vegetation. It is a fast growing, evergreen robust shrub, which can grow properly in areas having rainfall up to $700-1000 \mathrm{~mm}$. It grows densely in the degraded, open and moist slopes (Acharya, 2003). The most useful and valuable part of the plant is leaf, which is dark green in color and yield 0.3 to 0.9 percent of yellowish essential oil, the well known "Wintergreen oil" in commerce. The essential oil of this plant contains M ethyl Salicylate 95-97\%, widely used in allopathic and A yurvedic medicines, and in cosmetic products, flavors and medical preparations, including toothpaste to massage cream (ANSAB 2002).

According to local inhabitants, Wintergreen plant has a good regeneration capacity. The plants, which are not harvested ever, have few leaves and the harvested plants regenerate more leaves.

\section{Actors Involved in the Value Chain of Wintergreen:}

$V$ arious actors are involved in the essential oil value chains of Wintergreen. These different actor groups exhibit a mixture of economic background and outside exposure, and possess years of experience in this field. There is a clear distinction in the role played by these groups (see underneath).

\section{The $\mathrm{H}$ arvesters}

Wintergreen harvesters are predominantly female local inhabitants 
who reside 2-5 $\mathrm{km}$ from the forest. Some males al so collect Wintergreen but only occasionally. A typical Wintergreen harvester begins her day at sunrise by sharpening her hasiya (sickle) and trodding her way to areas where she will collect Wintergreen. She moves through the forest from one clump to another, cutting leaf-sheaths. The harvester returns and delivers the W intergreen to a processing unit. Thus, the task of collecting is categorized into travel to and from worksite, searching for and cutting Wintergreen, and carrying Wintergreen to a processing unit. Productivity of an extraction episode varies from one community forest to another. Interviews with the collectors, executive members of the CFUGs and local informants indicated that, in a 4-6 hour workday, one can collect approximately $60 \mathrm{~kg}$ of Wintergreen twigs with fresh leaves. In Suspa distillation unit, the price of $1 \mathrm{~kg}$ of Wintergreen was Rs.1.00, whereas in Khari Khola it was Rs 1.50. The reason given for the difference in price was the distance factor. Collectors had to spend 6 hours to reach the $\mathrm{K}$ hari $\mathrm{K}$ hola distillation unit whereas the same amount of W intergreen could be collected within 5 hours in Suspa. However, collectors at the Suspa distillation unit were expecting to sell Wintergreen at the same price the collectors of Khari Khola distillation obtained.

The average annual income from Wintergreen varies from one harvester to another depending on the availability of surplus labor and socioeconomic condition of the collector. Generally, harvesters were able to earn Rs. 1,000-2,000 per month along with their daily work at home. This amount is higher than the local wage rate of unskilled labor (Rs.50 per day for 8 hours of work). Income from W intergreen contributes 15-25 percent to the total household income of the harvesters. M ost of the harvesters have limited knowledge about the end use of Wintergreen.

Harvesters deliver raw Wintergreen to the distillation unit where a responsible person records the date received and weight of the product. $H$ arvesters either keep this information in their memory or maintain it at home. The responsible person gives the total amount of payable money to each collector weekly or biweekly. If the calculation of the payable money differs between the records of the distillation unit and the collector, they go through their records and settle the problem. Collectors mentioned some examples of this practice in both distillation units. They also mentioned that they had managed such differences without any difficulty. 
None of the collectors, however, had taken payment in advance from the owner of the distillation unit.

\section{The Community Forest U ser Group (CFUG)}

CFUGs are the key owners of raw Wintergreen because almost all Wintergreen is collected from community forests. There are a total of 278 CFUGs in Dolakha district. The role of CFUGs in the value chain has gradually increased in Dolakha due to the active role of ANSAB in promoting NTFPs by facilitating FECOFUN at the district as well as central levels. Without a close collaboration with the CFUGs, it would have been impossible to establish the Wintergreen oil distillation unit in the district. In close association with CFU Gs in their respective catchment areas, distillation units can be established individually or collectively.

Neither FECOFUN nor District Forest Office (DFO) has adequate data about the exact availability of Wintergreen in different community forests. However, available secondary data and discussions held with different stakeholders show that at least 6 distillation units can be managed in a sustainable manner in Dolakha district alone. Informants also mentioned that there are some potential areas for the establishment of distillation units in Sindhupalchowk district. The Forest Stewardship Council (FSC) certification process did assess for a few of the CFUGs the availability and suggested sustainable harvesting levels and also concluded that expansion could happen, but needed to be closely monitored. FSC requires annual field audits to check on forest and social conditions and as more groups can join the FSC certification, it is hoped that more CFUG areas will come under better management. The FSC certification report does give maximum harvest levels and monitoring and record keeping protocols to be observed. The initial areas that were certified for Wintergreen and other products just recently passed their first FSC audit.

After entering into an agreement with a distillation unit, CFUGS give permission to collect Wintergreen from their forest. Harvesters do not have to pay a royalty directly to CFUGs. CFUGs get NRs 0.25 per $\mathrm{kg}$ of raw Wintergreen from the owner of the distillation unit. The relationship between the distillation units and CFUGs was found to be 
90 Occasional Papers, Vol 11

good. The CFUGs give a letter of clearance to the local traders or marketing cooperative to export Wintergreen oil to Kathmandu.

\section{Primary Processors}

Two types of 1 primary processors are involved in Wintergreen oil production: privately owned and managed by cooperative. Cooperativemanaged enterprises are important not only for their financial benefits but also for their socio-economic benefits. This enterprise created parttime employment for about 300 community people through Wintergreen collection and fuelwood collection. It also employed six direct laborers in its daily activities. Wintergreen distillation units are located, as far as possible, near the community forest and villages. The processing unit is very simple where two laborers are required to work in each unit. Each laborer working at the distillation unit gets Rs. 3,000 per month (Rs. 100 per day) and two meals a day. These laborers are supposed to stay at the distillation unit for security reasons.

One person puts fresh Wintergreen leaves in the upper part of the vessel, while another prepares the fire by putting the marc (wastage) of the previous distillation under the same vessel. It takes about 250 kilos of raw Wintergreen to produce one kilo of oil. The lower part of the vessel contains water that will be transformed into the steam. The passage between the drum and the condenser has to be tightly closed to maintain the water steam inside the drum. Hard leaves of Wintergreen take about 2-3 hours to macerate. After 2-3 hours the worker stops the fire for about 6-8 hours and lights it again for 4-5 hours.

A skilled laborer opens the passage between the vessel and the condenser to let the distillation process take place. The steam charged with the essential oil is cooled in the condenser that contains a tube system where cold water flows. In this way, the distillation process lasts 8-10 hours for Wintergreen essential oil. The temperature of the tube connecting the second chamber and the condenser has to be steadily checked and the intensity of the fire maintained. The essential oil sublimes off, if the temperature exceeds 100 degrees Celsius.

The steam transforms into liquid and flows from the condenser to a container or a separator. At the end of the process, the essential oil is 
separated from the water. The essential oil from Wintergreen is heavier than water. The leaves are removed from the upper part of the drum and spread out to dry. They will feed the fire of the next distillation process. It was also mentioned that the amount of firewood required per day in K hari Khola and Suspa distillation unit were 25 and $10 \mathrm{~kg}$, respectively. The cost of one $\mathrm{kg}$ of firewood was one rupee. Some leakage problems were seen during the separation process of Wintergreen oil. The amount of W intergreen oil produced from each distillation process ranges between 2.2-2.5 kg per day. Had there not been the leakage problem, production of the oil could have been slightly higher. The oil produced is taken to Kathmandu. The traders do not have to pay any tax and royalty to others except the royalty to the CFUGs.

\section{District Level Traders}

District level traders buy Wintergreen oil from the primary processors. The price of one $\mathrm{kg}$ oil is NRs. 700 at the distillation unit. The village traders sell Wintergreen oil to the Herbs Production and Processing Company Limited (HPPCL), Kathmandu. The transportation cost per $\mathrm{kg}$ oil is NRs. 10. It was also mentioned that traders who can sell Wintergreen oil at the domestic manufacturer/retail market in $\mathrm{K}$ athmandu get more benefits compared to selling to $\mathrm{HPPCL}$.

\section{Domestic Manufacturers}

There are about $30 \mathrm{Nepali}$ manufacturers who use Wintergreen oil in various medical and toiletry-related preparations such as massage oil and toothpaste. $\mathrm{N}$ epali manufacturers prefer to buy Wintergreen oil from district level traders or cooperatives. They pay Nepali Rs. 950 (about US $\$ 13.50$ ) to buy one kilogram of oil from HPPCL but can get oil from district level traders for only Rs. 850 (about US $\$ 12.00$ ) per kilo of oil.

\section{National Trader and Marketing Cooperative}

The government owned Herbs Production and Processing Company Limited (HPPCL) in Kathmandu is one of the leading companies, which buys Wintergreen oil from district level traders and sells it to domestic 
manufacturers in Nepal. It also exports Wintergreen oil to India and European countries. HPPCL guarantees traders and cooperatives it will buy certain amounts of essential oil from different parts of $\mathrm{Nepal}$. According to official information from HPPCL, Wintergreen oil comes to the company from Dolakha district directly from the district level traders or via cooperatives depending on the nature of the ownership of the distillation unit. HPPCL uses Wintergreen oil for Sancho production (liquid medicine used against upper respiratory tract infections like the common cold and throat pain), sells to a domestic manufacturer, and

Table 1: Services and Skills along the Wintergreen Value Chain, Dolakha

\begin{tabular}{|l|c|l|}
\hline Market Actors & $\begin{array}{l}\text { Number } \\
\text { in } \mathbf{2 0 0 4}\end{array}$ & Services and Skills \\
\hline National Trader & 1 & $\begin{array}{l}\text { Buys Wintergreen oil from district level traders } \\
\text { and cooperativeSell it to Nepali manufacturers, } \\
\text { export to abroadExplore international market for } \\
\text { higher value addition }\end{array}$ \\
\hline $\begin{array}{l}\text { Nepali } \\
\text { manufacturers }\end{array}$ & 30 & $\begin{array}{l}\text { Use Winterg reen oil in different products } \\
\text { Buy Wintergreen oil from district level traders/ } \\
\text { cooperative national trader }\end{array}$ \\
\hline District level & 3 & $\begin{array}{l}\text { Supply oil to Nepali manufacturers and traders } \\
\text { national trader, arrange transport, store oil }\end{array}$ \\
\hline $\begin{array}{l}\text { Marketing } \\
\text { cooperative }\end{array}$ & 1 & $\begin{array}{l}\text { Gives opportunity for local people to invest } \\
\text { small scale enterprises;Provides market } \\
\text { information to CFUGs }\end{array}$ \\
\hline $\begin{array}{l}\text { Primary } \\
\text { processors }\end{array}$ & 350 & $\begin{array}{l}\text { Pay royalty to CFUGsBuy fuelwood from local } \\
\text { inhabitants, process oil, pay harvester so must } \\
\text { have working capital }\end{array}$ \\
\hline Harvesters & $\begin{array}{l}\text { Have skill to collect raw Wintergreen; Helps } \\
\text { processors providing raw Wintergreen on time; } \\
\text { Use surplus labor in income generating activities } \\
\text { Conduct biological monitoring 10 with CFUGs }\end{array}$ \\
\hline $\begin{array}{l}\text { CFUGs (resource } \\
\text { managers / } \\
\text { producers) }\end{array}$ & $\begin{array}{l}\text { Give opportunity to local inhabitants to } \\
\text { involve in income generating activities; Use } \\
\text { royalty for the forest management and other } \\
\text { social and economic development issues }\end{array}$ \\
\hline
\end{tabular}

Source: Field Survey, 2005 
exports to India and abroad. However, export of Wintergreen oil from $\mathrm{N}$ epal to third countries (other than India) is very small. With respect to market price, the district level traders and cooperative usually get higher prices from domestic manufacturers than the national trader. Thus, the domestic manufacturer/retailer is the first stop to sell Wintergreen oil in $\mathrm{K}$ athmandu. It was also mentioned that the share of Wintergreen oil in the international market is less than 10 percent. International buyers have commented that while the $\mathrm{N}$ epal W intergreen oil is unique (harvested from wild sources, high quality and most recently forest stewardship council (FSC) and organic certified) it must be placed in specialty markets as Chinese Wintergreen oil of much lower quality sells for a fraction of the price. Bulk international users of W intergreen oil buy almost exclusively on price and do not need the highest quality oil produced by $\mathrm{N}$ epal.

\section{Gross Output Values}

$M$ arket shares of the harvesters have increased due to the interventions from enterprise-oriented community forests, better access to market information, and local communities' awareness about the new income generation opportunities offered by this product.

Table 2: Price, Expenses and Margins for Wintergreen Oil

\begin{tabular}{|l|c|}
\hline Actors & $\begin{array}{l}\text { Prices/Expenses/Margins } \\
\text { (Rs./ Kg) 2005 }\end{array}$ \\
\hline $\begin{array}{l}\text { Prices } \\
\text { Local harvesters to local processing unit } \\
\text { (250 kg raw Wintergreen to produce one kg oil) }\end{array}$ & 312 \\
\hline Local processing unit to marketing cooperative (oil) & 700 \\
\hline Local processing unit to district level traders (oil) & 700 \\
\hline Cooperative to national trader & 800 \\
\hline Cooperative to domestic manufacturers (oil) & 850 \\
\hline National traders to domestic manufacturers (oil) & 950 \\
\hline National trader to Indian Market & 1400 \\
\hline National Trader to European and American market & 1700 \\
\hline $\begin{array}{l}\text { Expenses } \\
\text { Harvesting and transportation to local processing }\end{array}$ & \\
units by local harvesters (local cost of labor) & 250 \\
\hline
\end{tabular}


94 Occasional Papers, Vol 11

\begin{tabular}{|l|c|}
\hline Actors & $\begin{array}{l}\text { Prices/Expenses/Margins } \\
\text { (Rs./ Kg) 2005 }\end{array}$ \\
\hline $\begin{array}{l}\text { Conservation fee to CFUGs paid by local processors } \\
\text { Handling, fuelwood, staff, machines depreciation, } \\
\text { rents paid by local processors/cooperative }\end{array}$ & 62 \\
\hline $\begin{array}{l}\text { Handling and packaging paid by local trader/ } \\
\text { marketing cooperatives }\end{array}$ & 10 \\
\hline $\begin{array}{l}\text { Transportation to Kathmandu paid by } \\
\text { cooperatives/ local trader }\end{array}$ & 10 \\
\hline $\begin{array}{l}\text { Storage, quality testing, insurance, repackaging, } \\
\text { handling paid by national trader }\end{array}$ & 60 \\
\hline $\begin{array}{l}\text { Export permit, Department of Plant Resources } \\
\text { (DPR) tests and issues certification, sealed and } \\
\text { other costs paid by national trader to export India }\end{array}$ & 200 \\
\hline $\begin{array}{l}\text { Export permit, DPR test and certification, } \\
\text { sealed and other costs paid by national } \\
\text { trader to export Europe and America }\end{array}$ & \\
\hline $\begin{array}{l}\text { Margins } \\
\text { Harvesters }\end{array}$ & 300 \\
\hline Primary Processor & 62 \\
\hline Cooperative & 76 \\
\hline District level trader & 80 \\
\hline National Trader (if sold to domestic manufacturers) & 80 \\
\hline National Trader (if sold in India) & 540 \\
\hline National Trader (if sold to Europe and America) & 90 \\
\hline
\end{tabular}

Source: Field Survey and information obtained from HPPCL and HBTL, 2005.

\section{Employment and Sales Destination:}

Wintergreen harvesters are predominantly female local inhabitants who reside $2-5 \mathrm{~km}$ far from the forest. Some males also collect Wintergreen but only occasionally. Poor and marginalized local farmers are the main harvesters of Wintergreen.

The Herbs Production and Processing Company, Limited (HPPCL), $K$ athmandu is one of the leading companies, which buys and sells essential oil in $\mathrm{Nepal}$. It guarantees to buy certain amount of essential oil from different parts of $\mathrm{Nepal}$. According to HPPCL, Wintergreen oil comes to the company from Dolakha District either directly from the traders or 
via cooperatives depending on the nature of the ownership of the distillation unit. HPPCL uses Wintergreen oil for its own production of Sancho (liquid medicine used against, among others, upper respiratory tract infections like the common cold and throat pain), sells to retailers and Ayurvedic companies and firms, and exports to India and abroad. However, export of Wintergreen oil from N epal to third countries (other than India) is very small. With respect to the market price, the local contractors usually get higher prices from retailers and market traders in $\mathrm{K}$ athmandu who are trying to look for markets in Europe and America. Thus, retailers are the first preferred buyers of Wintergreen oil in Kathmandu. The share of Wintergreen oil in international market was reported to be less than 10 percent.

Table 3: Vertical Income and Profit for Wintergreen Oil

\begin{tabular}{|l|c|c|}
\hline Actors & Income Per Kg (Rs) & Profit Per Kg (Rs) \\
\hline Harvesters & $\mathbf{3 1 2}$ & $\mathbf{6 2}$ \\
\hline CFUGs & $\mathbf{6 2}$ & $\mathbf{5 0}$ \\
\hline Processors & 700 & 76 \\
\hline Marketing Cooperative & 850 & 80 \\
\hline District level trader & 850 & 80 \\
\hline $\begin{array}{l}\text { National Trader (for selling } \\
\text { in Indian Market) }\end{array}$ & 1400 & 340 \\
\hline $\begin{array}{l}\text { National Trader (for selling } \\
\text { in America or Europe) }\end{array}$ & 1700 & 540 \\
\hline
\end{tabular}

Source: Field Survey, 2005.

\section{Horizontal Distribution of Income and Profit :}

The average annual income from W intergreen varies among the harvesters depending on their household labor availability and socioeconomic condition. Generally, harvesters were able to earn Rs. 1,000-2,000 per month along with their daily work at home. This amount is higher than the local labor wage rate (Rs.50 with meals per day for 8 hours of work). Income from Wintergreen contributes 15-25 percent to the total household income of the harvesters. The processors and marketing cooperative are not sufficiently motivated to establish new Wintergreen 
96 Occasional Papers, Vol 11

processing units due to stagnant market price and monopoly price fixing by HPPCL.

Table 4: Power Mapping of Wintergreen

\begin{tabular}{|c|c|c|}
\hline MarketActors & Access Status & Mechanism of Exercising Access \\
\hline Local harvesters & $\begin{array}{l}\text { Access to forests, Direct } \\
\text { access to CFUG resources }\end{array}$ & CFUG membershipLocal inhabitants \\
\hline $\begin{array}{l}\text { Community } \\
\text { Forest User } \\
\text { Groups }\end{array}$ & $\begin{array}{l}\text { Access to local harvesters, } \\
\text { traders, market informa- } \\
\text { tion and various supporting } \\
\text { organizations }\end{array}$ & $\begin{array}{l}\text { CFUG membershipOwnership and mana- } \\
\text { gement rights of community forest } \\
\text { Networking with different governmental } \\
\text { and non governmental organizations }\end{array}$ \\
\hline $\begin{array}{l}\text { Primary } \\
\text { Processor }\end{array}$ & $\begin{array}{l}\text { Access to harvesters and } \\
\text { CFUGsAccess to district } \\
\text { level traders Local social } \\
\text { and eco-nomic network, } \\
\text { Access to market } \\
\text { information and other } \\
\text { supporting Organizations }\end{array}$ & $\begin{array}{l}\text { Good relationship with the harvesters } \\
\text { CFUGs Employment opportunities for } \\
\text { local community members Provide } \\
\text { economic opportunities for locals }\end{array}$ \\
\hline $\begin{array}{l}\text { District level } \\
\text { traders }\end{array}$ & $\begin{array}{l}\text { Access to processors, } \\
\text { domestic manufacturers } \\
\text { and national traders }\end{array}$ & $\begin{array}{l}\text { Good relationship with primary } \\
\text { processors, DFO and FECOFUN Social } \\
\text { and economic networking with primary } \\
\text { processors }\end{array}$ \\
\hline $\begin{array}{l}\text { Co-operative } \\
\text { Enterprises }\end{array}$ & $\begin{array}{l}\text { Access to CFUGs, domestic } \\
\text { manufacturers and } \\
\text { national traders Access to } \\
\text { market information and } \\
\text { supporting organization }\end{array}$ & $\begin{array}{l}\text { Good relationship with FCUGS, FECOFUN } \\
\text { and supporting organization. Support } \\
\text { from local community }\end{array}$ \\
\hline $\begin{array}{l}\text { Nepali } \\
\text { Manufacturers }\end{array}$ & $\begin{array}{l}\text { Access to district level } \\
\text { tradersAccess to inter- } \\
\text { national market on } \\
\text { minimal scale Access to } \\
\text { national trader Access to } \\
\text { people on behalf their } \\
\text { final product Knowledge } \\
\text { on market information }\end{array}$ & $\begin{array}{l}\text { Production popularity in national and } \\
\text { international market. Good network with } \\
\text { district and national tradersGood } \\
\text { network with custom international } \\
\text { markets Popularity of the product. }\end{array}$ \\
\hline National Traders & $\begin{array}{l}\text { Access to Nepali manu- } \\
\text { facturers, district level } \\
\text { traders and international } \\
\text { market. Access to market } \\
\text { information }\end{array}$ & $\begin{array}{l}\text { Network with international and Nepali } \\
\text { manufacturers;Quantity of purchasing } \\
\text { assurances to cooperatives, district level } \\
\text { traders and primary processors; Network } \\
\text { with international market }\end{array}$ \\
\hline
\end{tabular}

Source: Field survey 2005. 
Wintergreen is comparatively a new product. Compared to its full potential, its utilization has been minimal. A detailed feasibility study of this product in different districts is yet to be done. However, the following table provides the actual quantity harvested and the estimated annual production capacity of raw Wintergreen in various districts.

Table 5: Harvesting and Biological Capacity Status of Wintergreen in Nepal

\begin{tabular}{|r|l|c|c|c|}
\hline \multirow{2}{*}{ SN } & \multirow{2}{*}{ Districts } & Wintergreen & Annual Harvested & Annual \\
\cline { 2 - 5 } & $\begin{array}{c}\text { No of } \\
\text { Harvesters }\end{array}$ & $\begin{array}{c}\text { Quantity ( Kg) } \\
\text { (Average of Last 5 Years) }\end{array}$ & $\begin{array}{c}\text { Production Capacity } \\
\text { Kg/Year ( Potential) }\end{array}$ \\
\hline 1 & Solukhumbu & 0 & - & 400,000 \\
\hline 2 & Sankhuwasabha & 0 & - & 30,000 \\
\hline 3 & Pachthar & 0 & - & 7,000 \\
\hline 4 & Okhaldhunga & 0 & - & 150,000 \\
\hline 5 & Ilam & 0 & - & 50,000 \\
\hline 6 & Ramechhap & 100 & 100,000 & 400,000 \\
\hline 7 & Sindupalchok & 50 & 75,000 & 200,000 \\
\hline 8 & Nuwakot & 0 & 0 & 400,000 \\
\hline 9 & Rasuwa & 0 & 0 & 300,000 \\
\hline 10 & Dolakha & 200 & 160,000 & 700,000 \\
\hline 11 & Kavrepalanchok & 0 & 0 & 300,000 \\
\hline 12 & Lalitpur & 0 & 0 & 15,000 \\
\hline 13 & Dhading & 0 & 0 & 50,000 \\
\hline 14 & Makawanpur & 0 & 0 & 50,000 \\
\hline 15 & Bhaktapur & 0 & 0 & 50,000 \\
\hline 16 & Mygadi & 0 & 0 & 20,000 \\
\hline 17 & Baglung & 0 & 0 & 15,000 \\
\hline & Total & 350 & 335,000 & $1,437,000$ \\
\hline
\end{tabular}

Source: Essential oil production chart obtained from HBTL and information from different DFO Offices, 2005.

Productivity of a Wintergreen extraction episode varies from one community forest to another. Interview with the harvesters, executive members of CFUGs and local informants indicate that in a 4-6 hour workday, one can collect approximately $60 \mathrm{~kg}$ of Wintergreen twigs with fresh leaves. The value of one $\mathrm{kg}$ of Wintergreen varies from Rs. 
1.00 to Rs 1.50. The average annual income from Wintergreen varies from one collector to another depending on the availability of surplus labor and socioeconomic condition of the collector. Generally, harvesters were able to earn Rs. 1,000-2,000 per month along with their daily work at home. This amount is higher than the local wage labor rate (Rs.50 per day for 8 hours of work). Income from W intergreen contributes 15-25 percent to the total household income of the harvesters.

CFUGs are becoming stronger to manage local resources in D olakha. The government has given full authority to CFU Gs to manage W intergreen for income ingeneration. Coordination among DFO, FECOFUN, (I)NGOS and CFUGs is becoming stronger on market information, sustainable harvesting and ownership rights to the local inhabitants.

\section{Wealth/E conomic M apping:}

Collection and trade of NTFPs have played a key role in the economic development of the country where economic opportunities are severely constrained by difficult socio-economic condition and poorly developed infrastructures such as communication and transport facilities (A NSA B, 1999). For most of the communities, NTFP collection is one of the few or only ways to earn cash income without engaging in seasonal migration out of the area. Productivity of a Wintergreen extraction episode varies from one community forest to another. Interview with the harvesters, executive members of CFUGs and local informants indicate that in a 46 hour workday, one can collect approximately $60 \mathrm{~kg}$ of Wintergreen twigs with fresh leaves. The value of one $\mathrm{kg}$ of $W$ intergreen varies from Rs. 1.00 to Rs 1.50. The average annual income from $W$ intergreen varies from one collector to another depending on the availability of surplus labor and socioeconomic condition of the collector. Generally, harvesters were able to earn Rs. 1,000-2,000 per month along with their daily work at home. This amount is higher than the local wage labor rate (Rs. 50 per day for 8 hours of work). Income from W intergreen contributes 15-25 percent to the total household income of the harvesters.

\section{Power/Governance Mapping:}

CFUGs are becoming stronger to manage local resources in Dolakha. The government has given full authority to CFU Gs to manage W intergreen 
Table 6: Power Mapping of Wintergreen

\begin{tabular}{|c|c|c|}
\hline Market Actors & Access Status & Mechanism of Exercising Access \\
\hline Local harvesters & $\begin{array}{l}\text { Access to forests, Direct } \\
\text { access to CFUG resources }\end{array}$ & CFUG membershipLocal inhabitants \\
\hline $\begin{array}{l}\text { Community Forest } \\
\text { User Groups }\end{array}$ & $\begin{array}{l}\text { Access to local harvesters, } \\
\text { traders, market information } \\
\text { and various supporting } \\
\text { organizations }\end{array}$ & $\begin{array}{l}\text { CFUG membership Ownership and } \\
\text { management rights of community } \\
\text { forest Networking with different } \\
\text { governmental and non- } \\
\text { governmental organizations }\end{array}$ \\
\hline Primary Processor & $\begin{array}{l}\text { Access to harvesters and } \\
\text { CFUGsAccess to district level } \\
\text { tradersLocal social and } \\
\text { economic network, Access to } \\
\text { market information and other } \\
\text { supporting organizations }\end{array}$ & $\begin{array}{l}\text { Good relationship with the } \\
\text { harvesters CFUGs Employment } \\
\text { opportunities for local community } \\
\text { members Provide economic } \\
\text { opportunities for locals }\end{array}$ \\
\hline $\begin{array}{l}\text { District level } \\
\text { traders }\end{array}$ & $\begin{array}{l}\text { Access to processors, } \\
\text { domestic manufacturers and } \\
\text { national traders }\end{array}$ & $\begin{array}{l}\text { Good relationship with primary } \\
\text { processors, DFO, and } \\
\text { FECOFUNSocial and economic } \\
\text { networking with primary processors }\end{array}$ \\
\hline $\begin{array}{l}\text { Cooperative } \\
\text { Enterprises }\end{array}$ & $\begin{array}{l}\text { Access to CFUGs, domestic } \\
\text { manufacturers and national } \\
\text { traders Access to market } \\
\text { information and } \\
\text { supportingorganization }\end{array}$ & $\begin{array}{l}\text { Good relationship with FCUGs, } \\
\text { FECOFUN and supporting } \\
\text { organization. Support from local } \\
\text { community }\end{array}$ \\
\hline $\begin{array}{l}\text { Nepali } \\
\text { Manufacturers }\end{array}$ & $\begin{array}{l}\text { Access to district level } \\
\text { tradersAccess to } \\
\text { international market on } \\
\text { minimal scaleAccess to } \\
\text { national traderAccess to } \\
\text { people on behalf their final } \\
\text { product Knowledge on market } \\
\text { information }\end{array}$ & $\begin{array}{l}\text { Production popularity in national } \\
\text { and international market. Good } \\
\text { network with district and national } \\
\text { tradersGood network with custom } \\
\text { international marketsPopularity of } \\
\text { the product. }\end{array}$ \\
\hline National Traders & $\begin{array}{l}\text { Access to Nepali } \\
\text { manufacturers, district level } \\
\text { traders and international } \\
\text { marketAccess to market } \\
\text { information }\end{array}$ & $\begin{array}{l}\text { Network with international and } \\
\text { Nepali manufacturersQuantity of } \\
\text { purchasing assurances to } \\
\text { cooperatives, district level traders } \\
\text { and primary processors Network } \\
\text { with international market }\end{array}$ \\
\hline
\end{tabular}


for income ingeneration. Coordination among DFO, FECOFUN, (I)NGOS and CFUGs is becoming stronger on market information, sustainable harvesting and ownership rights to the local inhabitants.

Corruption in the Government agencies is a difficult reality for collectors, traders, and processors to overcome. Those with the financial means to address the needs of government officials, police officials, and forestry and customs agencies can profit within the current environment.

The government policy on forestry has enabled expansion of community forests across the country and devolved forest management rights and responsibilities to local community organizations (CFUGs). The community forestry program has significantly contributed to empowering the local people and ensuring sustainable utilization and management of locally occurring natural resources. It has been one of the most successful approaches in the forestry sector (Shrestha and Sharma 2004) in which the government transfers the responsibility of managing forests to the communities and recognizes the latter's right to use on a sustainable basis. V arious writers have noted its achievements in terms of better forest condition, social mobilization and income generation for rural development, and institutional building at the grass-root level ( $K$ Kanel 2004; Luintel, et. al, 2004; Shrestha and Sharma 2004).

Government policy with regard to NTFPs is not, however, perceived to be in favor of local communities in the same way as in the case of CF. It mainly tilts toward regulatory control in the name of maintaining ecological balance. As such, it has contributed little to solving problems affecting this sub-sector, and has often invited confrontation between the local people and the government. Luintel, et. al (2004) argue that such policies nurture a vicious circle of poverty.

\section{Conclusions:}

$\mathrm{N}$ atural resources are dynamic. Perception regarding their ownership and access right is socially embedded, and political forces determine the stake of various actors and stakeholders over such resources. People and their surrounding environment define resources and their use. The $N$ ature, Wealth and Power Framework enables one to understand the various cross-cutting themes. It is a mutually inclusive framework for knowledge 
management, capacity building, organizational development and arrangement, competitiveness and efficiencies, policy and legal reforms, and integration.

The essential oil products are mostly harvested from the forest for commercial purposes and are carried away from the villages and districts and are sold to the national and international markets. In general, the actors in the value chain at each level derive some benefits from NTFP trade. Wintergreen is an emerging product. There are high potentials for promoting essential oil products for income and employment generation in Nepal, made possible by the country's unique geo-climatic and ecological diversity.

M ost of the collectors Wintergreen were from poor and marginalized groups. CFUGs are generating substantial amounts of forest products and income. Substantial potentials also exist for further enhancing income through better management of community forests in $\mathrm{Nepal}$. However, fund mobilization guidelines should be prepared in consultation with different stakeholders so that income and expenditure of CFUGs become more transparent and geared towards pro-poor activities. In order to improve participation, inclusiveness, transparency and accountability in governance at the local level, more authority should be given to CFUGs with close supervision from DFO.

It is very important to link enterprises with well managed CFUGs to generate sufficient economic incentives and promote biodiversity conservation. Based on the experience from D olakha district, involvement of local people in establishing cooperatives appeared a preferred modality. Under-harvesting of Wintergreen was observed due to the presence of insufficient processing units, insufficient market demand, competition with Chinese products and insurgency. External support for the local communities is crucial in both conservation of biodiversity and reducing poverty within communities. M arket information and strategies of various players, starting from local harvesters to international traders, are substantially different and information gaps exist at each stage. Proper market information could ensure due return for each actor.

DFOs, CFUGs and entrepreneurs do not have adequate information on the availability of resources. The management plans are not based on 
production capacity of the given area. Similarly, enterprise planning is not based on resource availability. B oth collectors and district level traders suffer from poor market information, product price variation as well as uncertainty regarding future supply and demand of the products. As a result, business opportunities go untapped at the local level. It is exacerbated by inadequate fiscal incentives to community-based NTFP enterprises and bureaucratic harassment on commercial use of community forest resources. A favorable policy environment is a precondition in creating incentives and sustainable use of resources leading to biodiversity conversation.

\section{A cknowledgement}

I am grateful to ANSAB for the financial support to conduct this study, and Dr. Devendra Chapagain and Mr. Binod Pokhrel for their valuable suggestion and cooperation.

\section{R eferences}

A charya, Ram P. (2003). Assessment of M anagement $O$ ptions for E conomically Important Non-Timber Forest Products: A Case Study from Mid and High Hills of Nepal. An M. Phil. Dissertation Submitted to Indian Institute of Forest $M$ anagement, Bhopal.

A N SA B (1999). Subsector Analysis of High Altitude NTFPs in the Karnali Zone. A Report Submitted to Community-Based E conomic Development Project CBED/CECI Baluwatar, Kathmandu, Nepal.

A NSA B (2002). Inventory of Non-Timber Forest Products at Mimi, M elchham and Darma VDCs Humla, Nepal. Kathmandu: ANSA B

IIED (1998). Participatory Valuation of Wild Resources: An Overview of the $\mathrm{H}$ idden $\mathrm{H}$ arvest M ethodology. London: Sustainable A griculture and Rural Livelihood Program of International Institute for the Environment and Development (IIED).

IRG (2004). Nature, Wealth and Power: Emerging Best Practice for Revitalization Rural Africa. Washington: USAID in Collaboration with CIFOR, WINROCK, WRI and IRG.

Kanel, Keshav Raj (2004)." Twenty Five Y ears of Community Forestry: 
Contributing to M illennium D evelopment Goal" In 25 Years of Community Forestry: Contributing to Millennium Development Goal (pp 4-18). Kathmandu: Community Forest Division, Department of Forest.

Kaplinksy, R. and M. M orris (2001). A H and Book of Value Chain Research. IDRC.

L uintel, Harisharan, Mani Raj Banjade, Hari R. Neupane and Raj K. Pandey (2004). "Sustainable N on-Timber F orest Product M anagement: Issues and Ways Forward". In 25 Years of Community Forestry: Contributing to Millennium Development Goal. (pp 42- 47). Kathmandu: Community F orest Division, Department of Forest.

M eldelson, Samantha, Guy Cowlishaw and M arcus R owcliffe (2003). "A natomy of Bushmeat Commodity Chain in Takoradi, Ghana". The J ournal of Peasant Studies, Vol.31, No.1, pp73-100.

N ew ERA (2002). Final Program Performance Report of Ban U dyam. A Report Submitted to USAID.

Ojha, Hemant R. (2000). Current P olicy Issues in NTFP D evelopment in Nepal. Kathmandu: ANSAB.

Rawal, Rana B., Acharya, B. and Subedi, B.P (2001). Jaributi Marketing and Policy Issues in Nepal. Paper Presented at the N ational W orkshop on N onTimber Forest Products, February 22, 2001, Kathmandu.

Ribot, Jesse C. (1998). Theorizing Access: Forest P rofits along Senegal's Charcoal Commodity Chain. Development and Change V ol. 29. pp 307-341.

Shrestha, Raj Bahadur and Sharma, A nuja Raj (2004). "Sustainable M anagement of Community Forests: Towards Betterment of Rural Communities" . In 25 Years of Community Forestry: Contributing to Millennium Development Goal. Kathmandu: Community Forest Division, Department of F orest (Pp 31-41).

Subedi, Bhisma P. (1998). Participatory U tilization and Conservation of M edicinal and Aromatic Plants: A Case from Western Nepal Himalaya, Kathmandu: A sia Network for Small Scale Bioresources.

Y eh, Emily T. (1998). Forest Products, Foreign M arkets, and Conflict Between Tibetan Mushroom Harvesting Villages in South West China. A sia Forest Network, Working Paper Series. 2. 